\title{
NAZİ ALMANYASI İŞGALİNDEKİ POLONYA'DA PROPAGANDA POSTERLERI ÜZERINDEN YAHUDİLERE KARŞI NEFRET SÖYLEMİ İNŞASI
}

\author{
Caner Çakı* - Mehmet Ali Gazi**- Gül Çakı***
}

\section{ÖZET}

Polonya'da, İkinci Dünya Savaşı'ndan önce yaklaşık üç milyon Yahudi yaşamaktaydı. Bu sayı 1939 yılında Nazi Almanya'sının Polonya'yı işgal etmesinden sonra sistemli olarak azalmıştı. Naziler, işgali altında bulundurdukları Polonya'da Yahudilere karşı olumsuz bir imaj oluşturarak, Polonya halkının Yahudilere yardım etmesini önlemeyi, aynı zamanda Polonyalıların Yahudilerin saklandıkları yerleri ihbar etmelerini amaçlamıştır. Bu çalışmada Nazi propagandasının Polonya'da Yahudilere dinine karşı nefret söylemi inşasında posterleri nasıl ve ne şekilde kullandıkları incelenmiştir. Bu amaçla çalışmada Nazi propagandası tarafindan Polonya'da basılan ve günümüzde Amerika Birleşik Devletleri Holokost Anıt Müzesi'nde yer alan beş antisemitist propaganda posteri nefret söylemi bağlamında incelenmiştir. Çalışmada nitel araştırma yöntemlerinden göstergebilimsel analiz yöntemi kullanılmıştır. Çalışma kapsamında belirlenen Nazi propaganda posterleri, Fransız dilbilimci Roland Barthes'ın göstergebilim anlayışı ışığııda analiz edilmiştir. Elde edilen bulgular kapsamında, Nazi propaganda posterlerinde Yahudilerin yalnızca insanlığın kötülü̈̆̈̈̈ için çalıştı̆̆ına ve Hıristiyanlık dini için büyük bir tehlike oluşturdŭ̆una yönelik mitler inşa edildiği sonucuna ulaşılmıştır.

Anahtar Kelimeler: Yahudiler, Nefret Söylemi, Nazizm, Propaganda, Poster

\footnotetext{
* Arş. Gör., İnönü Üniversitesi, ORCID ID: http://orcid.org/0000-0002-1523-4649.

** Arş. Gör., Trabzon Üniversitesi, ORCID ID: https://orcid.org/0000-0002-9239-4187.

*** Yüksek Lisans Öğrencisi, Atılım Üniversitesi, gulcaki06@hotmail.com, ORCID ID: https://orcid.org/0000-0001-5501-0191

Makale Gönderim Tarihi: 14.03.2019- Makale Kabul Tarihi: 04.06.2019
} 


\title{
THE CONSTRUCTION OF HATE SPEECH AGAINST JEWRY ON PROPAGANDA POSTERS IN POLAND UNDER THE OCCUPATION OF NAZI GERMANY
}

\begin{abstract}
About three million Jews lived in Poland before the Second World War. This number fell systematically after the invasion of Poland by Nazi Germany in 1939. Nazis aimed at preventing that Polish people helped Jews by creating a negative image regarding Jews in the occupied Poland, while at the same time aiming that Polish people denounced the places where the Jews hided. In this study, how and in what way Nazi propaganda used posters in the construction of hate speech against Judaism religion in Poland was examined. To this end, five Jewish anti-religious propaganda published in Poland by Nazi propaganda and which are in the United States Holocaust Memorial Museum nowadays were examined in the context of hate speech. In this study, semiotic analysis method in qualitative research methods was used. Nazi propaganda posters determined within the scope of the study were analyzed in the light of semiotic understanding of French linguist Roland Barthes. In the light of the findings, it was concluded that myths that religion of Judaism only causedto wickedness of mankind and was a great danger for religion of Christianity were constructed Keywords: Judaism, Hate Speech, Nazism, Propaganda, Poster

\section{Gíriş}

30 Ocak 1933 tarihinde Nasyonal Sosyalist Alman İşçi Partisi (NSDAP), Almanya'da iktidara gelmişti. NSDAP, iktidarının ilk günlerinden itibaren antisemitist fikirlere sahip Nazizm ideolojisini Almanya'nın resmi ideolojisi haline getirmeye çalışmıştı. Bu süreçte Almanya'da Yahudi halkını dışlayan antisemitist kanunlaryürürlüğe girmeye başlamıştı. Naziler, yürürlüğe giren bu kanunlar sayesinde ülkedeki Yahudi nüfus üzerinde sıkı bir kontrol kurmayı başarmıştı. Naziler, İkinci Dünya Savaşı sırasında da işgal edilen ülkelerde Nazizm ideolojisini hakim kılmaya çalışmıştı. Bu ülkelerin başındada üç milyondan fazla 
Nazi Almanyası İşgalindeki Polonya'da Propaganda Posterleri Üzerinden Yahudilere...

Yahudi nüfusa sahip Polonya gelmekteydi ${ }^{1}$. Naziler, 1939 yılında Polonya'nın batı bölümünü, 1941 yılında da Polonya'nın tamamını işgal etmişti. Naziler, işgal altında bulunan diğer ülkelerde olduğu gibi Polonya'da da Yahudi nüfusu toplumdan soyutlayarak getto adı verilen yerleşim birimlerine göndermişti. Naziler, bu süreçte Yahudilere karşı uygulanan ayrımcılık politikalarında Polonya halkından destek görmek ve Polonya vatandaşlarının Yahudileri kendilerinden saklamalarını önlemek için Yahudilere karşı nefret söylemi içerikli yoğun bir propaganda faaliyetine yönelmiştir. Çalışmada Nazi propagandası tarafından Yahudilere karşı oluşturulan nefret söylemi kullanılan posterler üzerinden göstergebilimsel analiz tekniği kullanılarak açıklanmaya çalışılmıştır.

Son yıllarda Türkiye'de amtisemitizm, Nazizm ve Nazi propagandansı üzerine incelemede bulunan alanda önemli akademik çalışmaların yapıldığı görülmektedir. Bunlar içerisinde; "Türk Sinemasında Nazizm İdeolojisi: "Kırımlı" Filmi ve Göstergebilimsel Analizi" adlı çalışmada Nazizm ideolojisinin Türk sinemasındaki sunumu Kırımlı filmi özelinde analiz edilmiştir (Zorlu ve ark. 2017: 67). Elde edilen bulgular kapsamında Türk sinemasında Nazilere karşı ağırlıklı olarak nefret söylemi içeren ifadelere yer verildiği, diğer yandan Nazizm ideolojisinin öğretilerinin sert bir dille de eleştirildiği sonucuna ulaşılmıştır. "Adolf Hitler'in Kült Lider İnşasında Kullanılan Propaganda Posterlerinin Göstergebilimsel Analizi" adlı çalışmada Nazi propagandası tarafından dönemin Alman Devlet Başkanı Adolf Hitler'in kült lider olarak inşa edilmesinde posterlerin ne şekilde kullanıldı̆̆ı incelenmiştir (Çakı 2018a: 24). Elde edilen bulgularda, Almanya'nın dünyada güçlü bir devlet olabilmesi için Alman halkının Hitler'in emirleri doğrultusunda hareket etmesi ve Hitler'in aldığı kararların tartışılmaması gerektiğine yönelik algıların inşa edilmeye çalışıldığı ortaya

\footnotetext{
${ }^{1}$ Polonya'daki Yahudi nüfusu ile ilgili bilgiye https://www.jewishvirtuallibrary.org/poland-virtualjewish-history-tour linkinden 02.03.2019 tarihinde ulaşılmıştır.
} 
çıkarılmıştır. "Vichy Fransası'nda İşgal Propagandası" adlı çalışmada da Nazi Almanya'sının işgali altında bulunan Fransa'da Nazi işgal propagandasının ne amaçla kullanıldığı analiz edilmiştir (Çakı ve Gülada 2018a: 53). Çalışmada Nazi propagandasının, Müttefik Devletleri'ne karşı nefret söylemi inşa etmeye çalıştığı, buna karşın Almanya'nın Fransa'nın dost ve müttefiki olarak sunulduğu sonucuna ulaşılmıştır. "Waffen SS Askere Çağırma Propagandası" adlı çalışmada Nazilerin işgali altında bulunan ülkelerdeki halkın askere katılmalarını sağlamak için kullandığ1 propaganda posterleri incelenmiştir (Karaca 2018: 100). Çalışma sonucunda Nazilerin, Sovyetler Birliği ve Komünizm ideolojisini ortak düşman olarak sunarak, kitleleri etkilemeye çalıştığı görülmüştür. "Nazizm İdeolojisinde Alman Kadınları: NS-Frauen-Warte Propaganda Dergisi Üzerine İnceleme" adlı çalışmada Nazi propagandası tarafından Alman kadınlarının ne şekilde idealize edildiği ele alınmıştır (Çakı ve Gülada 2018b: 89). Çalışma sonucunda Alman kadınlarının İkinci Dünya Savaşı'nda önce iyi bir anne ve eş, İkinci Dünya Savaşı esnasında ise fabrikada, tarlada, hastanede çalışan iyi bir vatansever olarak idealize edildiği sonucuna ulaşılmıştır. Son olarak "Balkanlarda Bir Nazi Ordusu: Nazi Propaganda Afişlerinde Hançer Tümeni" adlı çalışmada Nazi propagandasının Balkanlarda yaşayan Müslümanları silahlandırarak nasıl kendi saflarına çekmeye çalıştı̆̆ı incelenmiştir (Çakı ve ark. 2018: 55). Çalışmada Nazilerin, Müslümanlar ile ortak düşmanlara sahip olduğu vurgusu üzerinden hem dini hem de ideolojik argümanları propaganda amaçlı etkili bir şekilde kullandığı sonucuna ulaşılmıştır.

Ulusal alanda yapılan akademik çalışmalar incelendiğinde Nazi Almanyası döneminde Yahudilere karşı nefret söylemi amaçlı yürütülen propaganda faaliyetlerini ele alanda her hangi bir çalışmaya rastlanılamamıştır. Bu amaçla çalışma alanda önemli bir boşluğu doldurması bakımından önem taşımaktadır. 


\section{NAZIZZM İDEOLOJISIININ YAHUDİLERE YÖNELİK BAKIŞI}

Nazizm ideolojisi, 20. yüzyılın ilk yarısında antisemitist, antikomünist, antikapitalist ve aşırı milliyetçiliğini tek çatı altında bir araya getiren bir dünya görüşü olarak ortaya çıkmıştı (Murray 1998: 42). Nazizm ideolojisi, 1922 yılında İtalya'da iktidara gelen Benito Mussolini'nin savunduğu Faşizm ideolojisi ile benzerlik taşısa da kendine özgü dinamikleri olan bir hayat görüşüdür (Mussolini 2016: 82). Nazizm ideololojisinin siyasi arenadaki temsilcisi ise Alman siyasetçi Adolf Hitler'in önderliğinde kurulan Nasyonal Sosyalist Alman İşçi Partisi (NSDAP) olmuştu. Nazizm ideolojisinin Almanya'da temsil edilmesi zaman içerisinde kavramın Almanya ile özdeşleşmesine neden olmuştu (Goodrick-Clarke 1993: 9). NSDAP, 24 Şubat 1920 tarihinde kurulduğu ilk günden itibaren Nazizm ideolojisini resmi ideolojisi olarak ön plana çıkarmıştı. NSDAP üyeleri zaman içerisinde partinin isimlerinin kısaltmalarından oluşan "Nazi" ismini kullanmaya başlamıştı. Naziler, Komünistler ve Yahudilere yönelik doğrudan nefret söylemine yönelmekteydi. Özellikle Nazilerin düşmanca tavırları doğrudan Yahudiler üzerine odaklanmaktaydı. Bunun altındaki temel neden Nazizm ideolojisinin güçlü antisemitist düşünceleri bünyesinde barındırıyor olmasıydı. NSDAP'ye üye olan herkesin Nazizm'in antisemitist fikirlerini de benimsemesi istenmekteydi.

Nazizm ideolojisinde, insanlar üstün ırk (ari ırk) ve aşağı ırk olarak iki temel sınıfa ayrılmaktaydı (Hyams 1995: 156). Bu sınıflandırma içerisinde başta Almanlar olmak üzere Kuzey İskandinav toplumları üstün 1rkı, diğer toplumlar ise aşağ ${ }_{1}$ 1rkı temsil etmekteydi (Neumann 2009: 39). Nazizm'e göre ari ırk üstün özellikleri ve liderlik becerisi ile alt ırkları yönetebilmekteydi. Bu aşamada Yahudiler ise her iki grubun da dışında sınıflandırılmaktaydı. Nazizm ideolojsine göre Yahudiler ari ırkın kötülügü için çalışan ve onları sömürmeyi hedefleyen tehlikeli bir grup olarak değerlendirmekteydi. Özellikle Nazizm ideolojisinin kuramcısı ve uygulayıcısı olan Hitler, doğrudan Yahudilere karşı nefret söylemi inşa 
etmekteydi (Macit 2007: 28). Nazizm ideolojisinin temelleri hakkında bilgi verdiği Kavgam (Mein Kampf) isimli kitabında doğrudan Yahudilerin ne kadar büyük bir sorun teşkil ettiğini ifade etmektedir(Hitler 2004: 380). Ari ırkın varlığını sürdürmesi ve egemenliğini dünyaya ilan edebilmesindeki en büyük engel Yahudiler olarak ön plana çıkarılmaktaydı. Bu nedenle Nazizm, ari ırkın Yahudilerden uzak durmasını ve hatta mücadele içerisine girmesini telkin etmekteydi (Passmore 2014: 146). Bunun sağlanabilmesi için ari ırka mensup bireylerin Yahudiler ile evlenmesinin engellenmesi gerektiği savunulmaktaydı. Ari ırk ve Yahudiler arasındaki evliliğin, ari ırkın saflığının bozulmasına neden olduğunu ileri sürmekteydi. Bu açıdan Nazizm ideolojisi, Nazilerin ne pahasına olursa olsun ari ırkın saflığını Yahudi tehlikesinden koruması gerektiğini savunmaktaydi.

Nazizm ideolojisi Yahudileri yalnızca Alman halkının veya ari ırkın değil, tüm dünyanın ortak bir sorunu olarak değerlendirmekteydi. Nazim başta Almanya olmak üzere tüm dünyanın sosyal, ekonomik ve siyasal yönden Yahudiler tarafından sömürüldüğünü savunmaktaydı. Bu nedenle antisemitizm Nazizm'de yoğun olarak görülmekteydi (Murray 1998: 42). Naziler, Yahudilerin yalnızca kendileri için çalıştıklarını, diğer insanların sömürülmesini veya aldatılmasını da meşru kabul ettiklerini iddia etmekteydi. Yahudilerin maddi çıkarları uğruna pek çok kötülüğe yönelebileceklerini savunmaktaydı. Bu nedenle Yahudilere olan düşmanlık Nazizm ideolojisinin bir parçası haline gelmişti (Yavuzoğlu 2003: 108). Nazizm ideolojisi hiç bir şekilde Yahudilere yönelik merhamete yer bırakmamaktaydı. Bu açıdan Yahudilerin sayısal olarak artmasının ari ırkın geleceğini doğrudan tehdit ettiğini savunmakta ve bu nedenle Yahudilere karşı ari ırkın mücalede içine girmesi gerektiğini belirtmekteydi. Nazizm'in bu görüşü, yaşamın bir mücadele alanı olduğu ve güçlünün zayıfa üstün geleceği yönündeki tezleri ile örtüşmekteydi. Bu açıdan ari ırkın kendini sağlık ve spor alanında geliştirmesi istenmekteydi (Çakı 2018b: 12). Diğer yandan Nazizm ideolojisi, 
Nazi Almanyası İşgalindeki Polonya'da Propaganda Posterleri Üzerinden Yahudilere...

Yahudileri Hıristiyanlık dininin en büyük tehlikesi olarak değerlendirmekteydi. Yahudilerin inançları gereği dünyanın dört bir yanındaki Hristiyanlara savaş açtığına ve Hristiyanyalığın baş düşmanı olarak hareket ettiklerine inanılmaktaydı. Bu süreçte -proganda amaçlı yürütülen faaliyetler hariç tutulursaNazizm ideolojsi Hıristiyanlık dininin savunuculuğunu kendi üzerine almamakta, yalnızca Hıristiyanları Yahudilere karşı uyarmaktaydı. Benzer şekilde Nazizm, Yahudilerin yalnızca kendilerine yardım ettiklerini ve kendilerinden olmayanları dışladıklarını iddia etmekteydi. Bu açıdan Yahudilerin birlik olma duyguları, ari ırkın güçlü bir düşman ile mücalede içerisinde olduğu algısını oluştumaktaydı.

Nazizm'de Yahudi sermayasine doğrudan savaş açılmaktaydı. Nazizm ideolojisine göre dünyadaki kapitalist sistem tamamen Yahudilerin elinde bulunmaktaydı. Bu yolla Yahudilerin insanları ekonomik olarak yönettiği ve onların gelirlerini sömürdükleri iddia edilmekteydi. Nazizm'e göre Yahudiler üretmek veya çalışmaktansa diğer insanların gelirlerine ortak olmaya çalışmaktaydı. Nazizm'in antikapitalist söylemlerinin her ne kadar Komünizm ideolojisi ile örtüştügü söylense de, Nazizm komünizmin tamamen Yahudiler tarafından çıkarılan sapkın ve tehlikeli bir ideoloji olduğunu belirtmekteydi. Nazizm, Yahudileri Almanya'nın geleceği önünde engel olarak tanımaktaydı (Keegan 2016: 296). Nazizm'e göre Komünizm, Yahudilerin kapitalist uygulamalarının dünya genelinde daha kolay tesis edilebilmesine yardımcı olmak için ortaya atılmıştı. Bu nedenle Nazizm'de antikomünist ve antikapitalist söylemler ile antisemitist söylemlerin içe içe geçtiği söylenebilmektedir. Diğer bir deyişle Nazizm, komünizm ve kapitalizme yönelik olumsuz söylemlerini doğrudan Yahudi karşıtı söylemleri ile temellendirmekteydi.

\section{NAZI ALMANYASI'NDA NEFRET SÖYLEMİ BAĞLAMINDA YAHUDİLERE YÖNELIKK YÜRÜTÜLEN PROPAGANDA FAALİYETLERİ}

Propaganda, belirli bir fikir, akım, düşünce veya idealin kitle iletişim araçlarından yararlanılarak belirli bir amaç doğrultusunda kitlelere tek yönlü iletişim kanalıyla 
aktarılmasını ve aktarılan fikirler doğrultusunda kitlelerin harekete geçmesini amaçlayan ikna odaklı bir iletişim türüdür. Diğer bir tanımla Propaganda, algıları biçimlendirmek, fikirleri manipüle etmek ve propagandacıların arzulanan niyetine yönelik bir tepkiyi elde etmek için yapılan kasıtlı, planlı ve sistematik bir girişimdir (Jowett ve O'donnell 2014: 7). Propaganda doğrudan kitleleri hedef almaktadır (Stanley 2018: 212). Propaganda disiplini insanlık tarihi kadar eski bir geçmişe sahiptir. Buna karşın 20. yüzyılda, gerek kitle iletişim araçlarında devrim niteliğinde yaşanan gelişmeler, gerekse propaganda odaklı kurulan totaliter rejimler, disiplinin altın çağını yaşamasına neden olmuştu. Propagandanın bu dönemde en etkili uygulayıcılarından biri Nazi Almanyası olmuştu (Domenach 2003: 40). Naziler, dönemin modern kitle iletişim araçlarını Nazizm ideolojisinin ülke genelinde tahakkümünü arttırmak ve aynı zamanda Yahudilere nefret söylemi inşa etmek için yoğun bir şekilde kullanmıştı. Naziler, NSDAP'nin kurulduğu ilk günlerden itibaren antisemist politikalarını kitlelere duyurmuş ve iktidara geldiklerinde antisemitist yasaların çıkarılması için var güçleri ile çalışacaklarını ifade etmişlerdi.

Nazilerin Yahudilere olan öfkesinin en somut örneği olarak Birinci Dünya Savaşı gösterilmekteydi. Nazilere göre Yahudiler Birinci Dünya Savaşı'ndaki Almanya'nın yenilgisinin baş sorumlusuydu. Nitekim Naziler'e göre, Alman ordusu savaşta yenilmemiş aksine Yahudiler Almanya'ya ihanet ederek Almanya'nın savaş dışı kalmasına neden olmuştu. Bu düşünce arkadan bıçaklanma (Dolchstoßlegende) olarak adlandırılmaktaydı (Seiler 1966: 1). Nazilerin bu savı, ülkedeki milliyetçi grupların NSDAP çatısı altında birleşmesinde önemli bir rol oynamaktaydı. Diğer yandan Nazi propagandası, Alman ordusunun yenilgisini kabullenmeyerek, Alman ırkınının yüceltilmesini de amaçlamaktaydı. Onlara göre Almanya'nın 1919 yılında utanç verici maddeler içeren Versay Antlaşması'nı imzalamasının, ağır bir savaş tazminatını ödemesinin, büyük toprak kayıplarına uğramasının da temel sorumlusu olarak Yahudiler 
Nazi Almanyası İşgalindeki Polonya'da Propaganda Posterleri Üzerinden Yahudilere...

olmuştu. Bu şekilde Naziler, savaş sonrası Alman toplumunda sosyal, siyasal ve ekonomik nedenler yüzünden oluşan nefreti doğrudan Yahudiler üzerine kanalize etmeye çalışmıştı (Çakı 2019: 216).

Nazilerin Yahudilere karşı nefret söyleminde Dr. Joseph Goebbelsönemli rol oynamaktaydı. Goebbels'in propaganda taktikleri Nazilerin kitleler nezdinde güç kazanmasını sağlamaktaydı (Eberle ve Uhl 2017: 547). Goebbels, Nazi propagandasında göstermiş olduğu başarılardan dolayı, Naziler iktidara geldiklerinde Halkı Aydınlatma ve Propaganda Bakanlığı görevine getirilmişti (Yücel, 2017: 154). Goebbels, partisinin antisemitist politikalarında geniş kitlelerden destek alabilmek için Yahudiler ve Komünistlerin iş birliği içerisinde çalıştı̆̆ını iddia eden propaganda faaliyetlerine yönelmişti. Böylece Almanya'nın genelinde önemli bir güç haline gelen antikomünist kitlelerin desteğini arkasına almayı amaçlamıştı. Goebbels, Yahudilerin Sovyetler Birliği'ndeki komünist liderleri tahakküm altına aldığını ve onları istedikleri gibi yönlendirdiklerini iddia etmişti. Yürütülen bu propaganda ile Almanya'da komünistlere karşı olan Alman vatandaşlarında, antisemitist fikirlerin de fizilenmesi amaçlamıştı (Goebbels 2016: 63). Goebbels tarafından yönetilen propaganda posterlerinde, kartpostallarında, gazetelerde, dergilerde ve hatta sinema filmlerinde bile Komünizm ve Yahudiğinaynı kavramlar olduğunu vurgulanmaya çalışılmıştı. Goebbels'in propagandası bir komünistin aynı zamanda bir Yahudi olduğu algısını ülke genelinde inşa etmek istemişti.

Naziler, 30 Ocak 1933 tarihinde iktidara geldiklerinde Yahudilere yönelik eylemlerini daha kapsamlı ve etkili bir şekilde yürütme olanağı bulmuşlardı. Nazi rejiminin iktidarının ilk yılından itibaren Nazi propagandası, Alman halkının Yahudi esnaftan alışveriş yapmamalarını telkin etmişti. Bunun için Naziler, Alman halkının ülke genelindeki tüm Yahudilerin işyerlerini boykot etmelerini istemişti (Mcdonough 2015: 195). Naziler iktidara geldikten iki yıl sonra Almanya'da güçlü bir antisemitist algının oluşmasını sağlamıştı. Bu süreçte Nazi propagandası 
ülkedeki tüm kitle iletişim araçlarını kullanarak Yahudilere yönelik güçlü bir nefret söylemi gerekleştirilmişti. Özellikle NSDAP'nin resmi parti gazetesi Völkischer Beobachter (Halkın Gözlemcisi) üzerinden Yahudilerin Alman tarihinde yapmış olduğu iddia edilen ihanetlerine yer verilmiş, sözde Yahudilerin Nazi Almanyası'nın geleceğini ipotek altına almak için ne gibi kirli planlar yaptığı ortaya koyulmuştu. Nazilerin antisemitist propagandası zaman içerisinde meyvesini vermiş ve 15 Eylül 1935 tarihinde Nazi rejimi tarafından Nürnberg Kanunları'nın kabul edilmesine zemin hazırlamıştı. Nürnberg Kanunları kapsamında Naziler, resmi olarak Yahudileri doğrudan alt ırktan insanlar olarak sınıflandırmıştı. Bu kapsamda Yahudilerin eczacılık, doktorluk, askerlik gibi meslekleri yapmaları yasaklanmıştı. Diğer yandan yeni yasalar kapsamında Yahudilerin ari irk bir vatandaş ile evlenmesine de "ırkın hijyenini koruma" amacıyla izin verilmemişti (Kershaw 2007: 593). Böylece Yahudiler, Alman toplumu içerisinde ötekileştirilmeye ve dışlanmaya başlanmıştı.

Nürnberg Yasaları'nın yürürlüğe girmesinden sonra Yahudilerin Almanya'daki yaşam şartları her geçen gün daha da zorlaşmıştı. Nazilerin ülkedeki nüfuzunu her geçen gün daha da güçlendirmesi, Yahudilerin Almanya'da daha fazla ayrımcılığa uğramasına neden olmuştu (Kershaw 2009: 157). Nazi propagandası Yahudilere yönelik nefret söylemi inşasında sinema filmlerini de etkili bir şekilde kullanmaya başlamıştı. Nazilerin antisemitist propaganda filmleri toplumun Yahudilere doğrudan nefret duygularını körüklemeye odaklanmıştı. Naziler, Yahudilerin dükkanları üzerine belirli yazılar yazarak veya işaretler koyarak, Alman vatandaşlarının Yahudilerden alış veriş yapmasını önlemeye çalışmıştı. Nihayetinde antisemitist propagandanın da etkisiyle 9-10 Kasım 1938 tarihinde Naziler, Kristal Gece (Kristallnacht) adı verilen Yahudi karşıtı büyük bir şiddet eylemi gerçekleştirmişti. Yahudilere yönelik gerçekleştirilen şiddet eyleminin neticesinde Yahudilere ait yüzlerce ev, işyeri ve sinagog tahrip edilmişti. Eylemler sırasında yüzlerce Yahudi hayatını kaybetmişti. Kristal Gece, Nazilerin Yahudilere 
Nazi Almanyası İşgalindeki Polonya'da Propaganda Posterleri Üzerinden Yahudilere...

karşı nefret söylemlerini, şiddet eylemlerine çevirdiği bir dönemin de başlangıcı olmuştu.

1 Eylül 1939 tarihinde Nazi Almanyası'nın Polonya işgali ile İkinci Dünya Savaşı başlamıştı (Macksey 2012: 19). Naziler, bu süreçte binlerce Yahudi'yi çalışma kamplarına (diğer bir adıyla toplama kamplarına) göndermişti. Benzer şekilde Yahudilerin bulundukları yerlerden farklı yerlere sürülmeleri de gerçekleşmekteydi (Mazower 2014: 572-573). Naziler, 1942 yllına gelindiğinde Avrupa'nın pek çok ülkesini işgal etmiş ve kıtanın büyük bir bölümünde kontrol kurmayı başarmıştı (Mcnab 2015: 179). Nazi Almanyası'nın işgali altında bulunan yerlerde Naziler, Yahudileri getto adı verilen yerleşim yerlerine almış ve Yahudileri halktan izole etmişti. Bu süreçte Avrupa'da bulunan Yahudi nüfusun önemli bir kısmı ABD'ye veya tarafsız ülkelere göç etmişti. Özellikle Almanya ve Avusturya'da göç dalgası yaşanmıştı (Beyerchen 2015: 73). Göç edemeyen Yahudiler, Nazilerin toplama kamplarında tutulmaya başlanmıştı. Bir kısım Yahudi ise Avrupa'da kalarak Nazilerden saklanma yolunu seçmişti. Bu aşamada Alman gizli polisi Gestapo, Avrupa'da saklanan Yahudileri yönelik kapsamlı bir iz sürme politikası uygulamıştı. Yakalanan Yahudiler toplama kamplarına gönderilmekteydi (Dalerne 2013: 290). Naziler, İkinci Dünya Savaşı süresince işgal ettiği ülkelerde de yoğun bir şekilde antisemitist propagandaya devam etmişti. Nazi propagandası tıpkı Almanya'da olduğu gibi işgal altındaki ülkelerde de kitleleri Yahudilerin insanlık adına büyük bir tehlike oluşturduğuna inandırmaya çalışmıştı. Bu süreçte Naziler, işgal atındaki ülkelerde kurulan Nazi yanlısı hükümetlerden yardım alma yoluna gitmişti.

Naziler 1943 yılından itibaren Müttefik Devletleri'ne karşı ağır yenilgiler almaya başlamıştı (Hart 2015: 677). Naziler, farklı cephelerde ABD, Sovyetler Birliği, İngiltere ve onların müttefikleri ile aynı anda savaşmaktaydı (Mcmahon 2013: 31). Bu aşamada Nazi propagandası antisemitist söylemlerine devam etmiş, Nazi Almanyası'nın dünya genelinde Yahudilere karşı mücadelesinin Alman 
ordularının mutlak zaferi kazanıncaya kadar süreceğini belirtmişti. Hitler, intiharına kadar giden süreçte son ana kadar Yahudilerin Alman toplumu için büyük bir tehlike oluşturduğunu iddia etmişti (Hitler 2005: 83). Naziler, bu süreçte Müttefik Devletleri'ne karşı Alman halkını seferber edebilmek için antisemitist propagandadan yararlanma yoluna gitmişti. Nazi propagandası, Nazi Almanyası'na karşı savaşan Müttefik Devletleri'nin doğrudan Yahudiler tarafından yönetildiğini savunmuş, Alman ordularının verdiği mücadelenin Müttefik Devletlerden ziyade Yahudilere karşı verildiğini iddia etmişti. Böylece Naziler, Yahudilere karşı oluşturdukları nefret söyleminden yararlanarak Müttefik Devletleri'ne karşı ülke genelinde güçlü bir birliğin inşa edilebileceğini planlamiştı.

1945 yılında Müttefik Devletleri, Almanya'yı işgal edip, Nazi rejimine son verdiklerinde, savaş sırasında yüzbinlerce Yahudinin toplama kamplarında hayatlarını kaybettiğini keşfetmişti. Bu süreçte yüzbinlerce Yahudinin ölümüne neden olacak uygulamalarda antisemitist propaganda faaliyetlerinin kitleler üzerinde ne kadar büyük bir etki bıraktığı da anlaşılmıştı.

\section{YÖNTEM}

\section{1. Çalışmanın Amacı}

1939-1944 yılları arasında Nazi Almanya'sının işgali altında kalan Polonya'da Yahudilere yönelik uygulanan yaptırımlarda Polonya halkından destek alabilmek için Nazi Almanya'sı tarafından Yahudilere nefret söylemi bağlamında ne tür propaganda uygulandığını ortaya koymak çalışmanın temel amacını oluşturmaktadır. Bu şekilde bir dine karşı nefret söylemi inşasında propagandanın nasıl kullanılabildiğinin açıklanması amaçlanmaktadır. 
Nazi Almanyası İşgalindeki Polonya'da Propaganda Posterleri Üzerinden Yahudilere...

\section{2. Çalışmanın Önemi}

Çalışma;

- Nazi Almanya'sı işgali altındaki Polonya'da Yahudilere karşı Nazi propagandası tarafından oluşturulan nefret söylemini açıklaması,

- İkinci Dünya Savaşı'ndaki Nazi propaganda faaliyetleri hakkında bilgi vermesi,

- Propagandada nefret söylemi kavramının nasıl ve ne şekilde kullanılabildiğini ortaya koymasi,

- Ulusal alanda yapılan akademik çalışmalar içerisinde özgün değer taşıması gibi nedenlerden dolayı önem taşımaktadır.

\section{3. Çalışmanın Evreni ve Örneklemi}

Nazi propagandası tarafından Yahudilere karşı nefret söylemi inşa etmek amacıyla kullanılan tüm propaganda posterleri çalışmanın evrenini oluşturmaktadır. Buna karşın çalışma kapsamında tüm posterlere ulaşmanın güçlüğünden dolayı çalışmada örneklem kullanılması yoluna gidilmiştir. Bu amaçla çalışma kapsamında Amerika Birleşik Devletleri Holokost Anıt Müzesi'nde yer alan beş adet Yahudilere karşıtı propaganda posteri çalışmanın örneklemi olarak belirlenmiştir ${ }^{2}$. Posterlerin doğrudan Yahudilere karşı nefret oluşturması ve Nazi propagandasının kült eserleri haline gelmesi nedeniyle çalışmanın örneklemi olarak belirlenmiştir.

\section{4. Çalışmanın Sınırlılıkları}

Çalışma kapsamında yalnızca beş propaganda posteri üzerinden Nazi Almanya'sının Polonya'yı işgali döneminde Yahudilere karşı nefret söyleminin analiz edilmesi ve elde edilen bulgular kapsaminda genellemelerde bulunulması çalışmanın temel sınırlılığını oluşturmaktadır.

2 Propaganda posterlerine, https://collections.ushmm.org/search/catalog/irn545098, linkinden 25.02.2019 tarihinde ulaşılmıştır. 


\section{5. Çalışmanın Sorulan}

Çalışma kapsamında aşağıdaki sorulara yanıt aranmaya çalışılmıştır;

Nazi Almanya'sının Polonya'yı işgali döneminde, Nazi propaganda posterlerinde Yahudilere yönelik nefret söyleminde;

- Hangi konular ön plana çıkarılmaktadır?

- Yahudi halkına yönelik ne tür mitler inşa edilmektedir?

- Yahudi halkı hangi metaforlar üzerinden sunulmaktadır?

\section{6. Çalışmanın Yöntemi}

Çalışmada nitel araştırma yöntemlerinden göstergebilimsel analiz yöntemi kullanılmıştır. Çalışma kapsamında Nazi propagandası tarafından basılan posterler Fransız dilbilimci Roland Barthes'ın göstergebilim anlayışı ışı̆̆ında analiz edilmiştir.

Gösterge, bir kavramın başka bir kavramı temsil etmesi ve onun yerine kullanılmasını ifade etmektedir. Göstergebilim de göstergeler yoluyla inşa edilen anlamlar üzerinde incelemede bulunan bir bilim dalıdır (Rifat 2013: 100-101). Göstergebilim, 20. yüzyılın ilk yarısında dilbilimciler Ferdinand de Saussure ve Charles Sanders Peirce'in yapmış olduğu çalışmalar ile ortaya çıkmıştır (Gazi ve ark. 2018: 16). Daha sonra farklı bilim dallarındaki felsefecilerin katkılarıyla günümüzde sosyal bilimler alanında etkin bir şekilde kullanılan bir araştırma yöntemi haline gelmiştir. Göstergebilim ilk olarak dilbilimi alanındaki çalışmalar ile ön plana çıkmıştır. Bu açıdan ilk ortaya çıktı̆̆ı dönemde göstergebilim, dilbiliminin bir parçası olarak düşünülmekteydi. Bu algının kırılmasında Fransız dilbilimci Roland Barthes'ın büyük katkısı olmuştur. Nitekim göstergebilim, çok geniş bir alanı kapsamaktadır (Tekinalp ve Uzun 2013: 139). Barthes, göstergebilimin sadece dilbilimi alanında sınırlandırılmaması gerektiğini savunmuştur (Barthes 2017: 87). Barthes, göstergebilim alanındaki eserleriyle göstergebilimsel analizleri fotoğraf, resim, müzik, film gibi pek çok farklı alana 
Nazi Almanyası İşgalindeki Polonya'da Propaganda Posterleri Üzerinden Yahudilere...

taşımıştır. Barthes'ın katkılarıyla birlikte göstergebilimin dilbiliminin bir parçası değil, dilbiliminin göstergebilimin bir parçası olduğu görüşü etkin olmaya başlamıştır.

Barthes, göstergebilimin düzanlam ve yananlam olmak üzere iki şekilde temellendiğini savunmuştur (Barthes 2016: 20). Düzanlam, göstergenin evrensel, kişiden kişiye değişmeyen, herkes tarafından kabul edilen anlamını ifade etmektedir. Yananlam ise tamamen düzanlamın zıttı bir kavramı ifade etmektedir. Yananlam, göstergenin değişebilen, kültüre özgü, öznel anlamı açıklamaktadır (Barthes 2015: 7-18). Örneğin, siyah bir kedi düzanlamda bir hayvanı, yananlam açısından ise şanssızlığı temsil edebilmektedir (Gazi ve Çakı 2018: 53). Barthes, yananlamların kültürden kültüre farklılaşabildiğini belirtmektedir. Bu açıdan kültür içerinde verilen yananlamların doğru okunabilmesi için yananlamın oluştuğu kültürün iyi bilinmesi gerekmektedir (Tanyeri Mazıcı ve Çakı 2018: 296). Barthes, yananlam ile birlikte mit kavramı üzerinde önemle durmaktadır. Mit, kültürlerin yaşananları anlamlandırma ihtiyacı içerisinde meydana getirdikleri inanış, düşünce veya öyküleri ifade etmektedir. Mitler, bir kültür içerisinde zamanla oluşabilmekte veya yapay olarak kitle iletişim araçlarının etkisiyle egemen güçler tarafından bilinçli bir şekilde meydana getirilebilmektedir. $\mathrm{Bu}$ aşamada medya üzerinde hâkimiyet kuran egemen güçler istedikleri mitin toplumda hâkim olmasını sağlayabilmektedir (Yaylagül 2017: 123). Böylece egemen yapı toplum üzerinde kontrol kurabilmektedir. Yapay anlanlamlar zaman içinde doğallaşabilmektedir (Barthes 2014: 25). Barthes'ın göstergebilim 1şığında analizlerde bulunulurken, metafor, metonimi ve simge kavramları da ön plana çıkabilmektedir. Metonimi, ilişki içerisinde bulunan bir kavramın başka bir kavram yerine kullanılmasını açıklamaktadır Metafor ise, birbirleriyle ilişkili olan veya olmayan iki kavramdan birinin diğeri yerine kullanılmasını ifade etmektedir (Guiraud 2016: 146). Simge de, birbirleri arasındaki ilişki olmayan iki kavramdan 
birinin toplum içerisinde oluşan uzlaşı içerisinde diğerini temsil etmesi olarak tanımlanmaktadır (Fiske 2017: 133).

Şekil 1: Roland Barthes'in Anlamlandırma Modeli

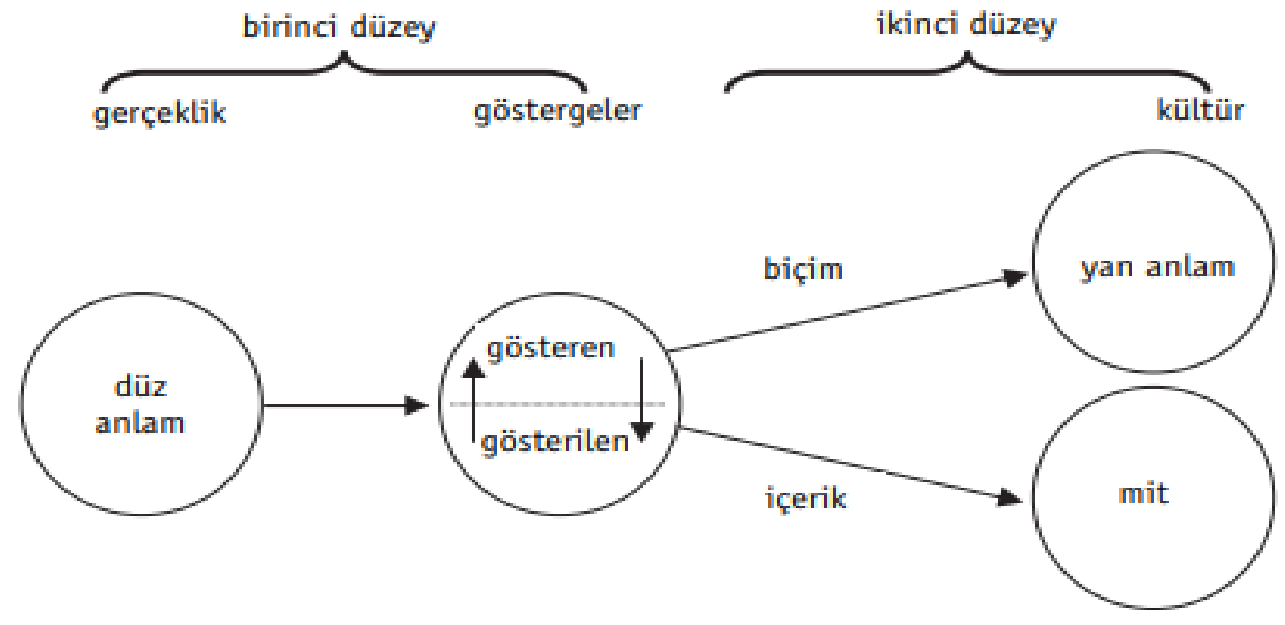

(Kaynak: Fiske, 2017: 186)

\section{ANALIZ}

Çalışmanın bu bölümünde "Kırbaç", "Hastalık", "Düşman", "Tehdit" ve "Kötülük" başlıklı beş adet propaganda posteri göstergebilimsel açıdan incelenmiştir.

\section{1. "Kurbaç" Konulu Propaganda Posteri}

"Kırbaç" konulu propaganda posteri düzanlam boyutunda ele alındığında, posterde devasa boyutta bir adamın bir yöne doğru ilerlemekte olan halkı kırbaçladığı resmedilmektedir. Poster, 1943 yılında Nazi propagandası tarafından kullanılmıştır. Görsel kodlar içerisinde elinde kırbaç olan adam siyah tonlar içerisinde yansıtılmakta, üstünde ise büyük altıgen bir yıldız bulunmaktadır. Adam sol elini yumruk yapıp sıkarken, sağ eli ile de halkı kırbaçlamaktadır. Kırbaçlayan adamın saçları ise bukleli olarak aktarılmaktadır. Sunum kodları içerisinde kırbaçlanan halk üzgün ve yorgun, kırbaçlayan adam ise nefret içerisinde yansitılmaktadır. İnsanların bulunduğu alan yer küre olarak 
Nazi Almanyası İşgalindeki Polonya'da Propaganda Posterleri Üzerinden Yahudilere...

belirtilmektedir. Postere kırmızı tonlar hâkim olmaktadır. Posterde "Bicz ludzkosci / İnsanlığın Belası" şeklinde yazılı kod bulunmaktadır.

Resim 1. "Kırbaç" Konulu Propaganda Posteri

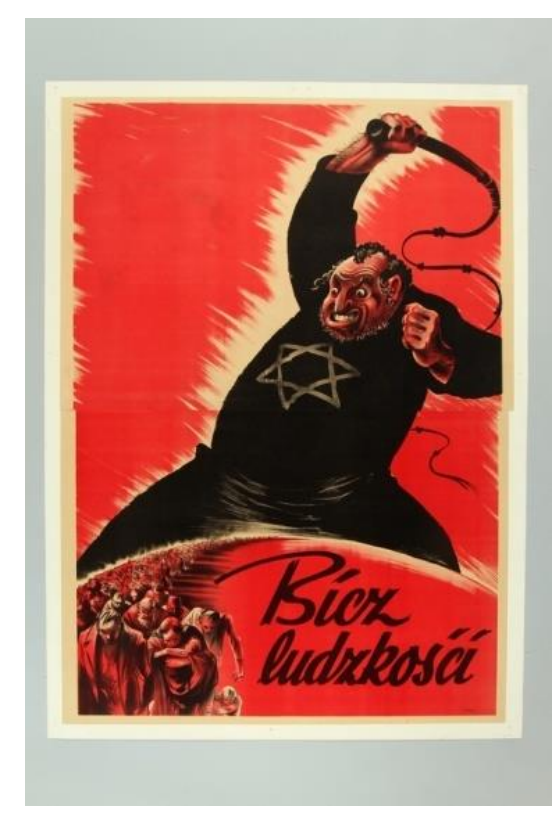

Propaganda posteri yananlam boyutunda incelendiğinde, posterde Yahudilerin insanlığ1 sömürdüğüne ve zulmettiğine vurgu yapılmaktadır. Görsel kodlar içerisinde insanların yer kürenin üzerinde bulunması, Yahudiler dışındaki tüm insanlığın zulme uğradığı mesajının oluşmasına neden olmaktadır. Bu açıdan posterde yer alan insanlar dünya halkının, kırbaçlayan Yahudi ise tüm insanlığın metonimi olarak posterde yer almıştır. Posterde Yahudiliği doğrudan simgeleyen ise altıgen yıldız olmaktadır. Sunum kodlarında insanların üzgün ve bitkin olarak yansıtılması, insanlığın sözde Yahudilerin baskılarından kurtulmak istediğinin bir yansıması olarak aktarılmaktadır. Buna karşın yine sunum kodlarında Yahudi'nin sinirli yansıtılması ile de Yahudilere yönelik korkutucu bir algının oluşması amaçlanmaktadır. Bu açıdan posterde yer alan Yahudi, zulüm metaforu olarak kitlelere aktarılmaktadır. Posterde yer alan "İnsanlığın Belası" şeklindeki yazılı kod ile doğrudan Yahudilere yönelik bir nefret söylemi inşa edilmeye çalışılmıştır. Posterdeki gerek görsel gerekse yazılı kodlar bir bütün olarak okunduğunda da, 
Nazi propagandasının posterde "Musevi dinine mensup insanların yegâne amacı insanoğluna zulmetmektir" şeklinde bir mitin Polonya kamuoyunda inşa edilmesi için çalıştığı görülmektedir. Bu yolla Polonya halkının, Yahudileri kendileri için büyük bir tehdit olarak algılamaları ve Naziler tarafından Yahudilere yönelik gerçekleştirilen uygulamalara karşı muhalefet etmemeleri amaçlanmıştır.

Tablo 1. "Kırbaç" Konulu Propaganda Posteri

\begin{tabular}{|c|c|}
\hline Düzanlam & Yahudi bir adamın insanları kırbaçlaması \\
\hline Yananlam & $\begin{array}{c}\text { Yahudilerin dünyadaki bütün kötülüklerin temelini } \\
\text { oluşturdukları ve insanoğlunu sömürdüğü iddia edilmektedir }\end{array}$ \\
\hline Mit & $\begin{array}{c}\text { Musevi dinine mensup insanların yegâne amacı insanoğluna } \\
\text { zulmetmektir }\end{array}$ \\
\hline Metafor & Kırbaç, zulüm metaforu olarak kullanılmaktadır \\
\hline Simge & Altıgen yıldız Musevilik dinini temsil etmektedir \\
\hline Metonimi & $\begin{array}{c}\text { Posterde resmedilen Yahudi tüm Yahudilerin, kırbaçlanan halk } \\
\text { ise Yahudilerin sözde zulmüne uğrayan insanlı̆̆ın metonimi } \\
\text { olarak kullanılmaktadır }\end{array}$ \\
\hline
\end{tabular}

\section{2. "Hastalık" Konulu Propaganda Posteri}

"Hastalık" konulu propaganda posteri düzanlam açısından incelendiğinde, posterde yaşlı bir Yahudi'ye yer verildiği görülmektedir. Poster, 1941 yılında Nazi propagandası tarafından kullanılmıştır. Görsel kodlarda Yahudi'nin yere çömeldiği ve üzerini kaşıdığı aktarılmaktadır. Yahudi'nin solunda Musevilik'in simgesi altıgen yıldız, sağında ise büyük bir kuru kafa bulunmaktadır. Posterdeki Yahudi'nin üzerinde büyük böceklerin gezdiği yansıtılmaktadır. Posterin arka 
Nazi Almanyası İşgalindeki Polonya'da Propaganda Posterleri Üzerinden Yahudilere...

planı ise karanlık olarak verilmektedir. Posterde "Strzez Sie Tyfusu Plamistego, Unika Zydow /Kendinizi Tifüs'ten Koruyun, Yahudilerden Kaçının" şeklinde yazılı kod bulunmaktadır.

Resim 2. "Hastalık" Konulu Propaganda Posteri

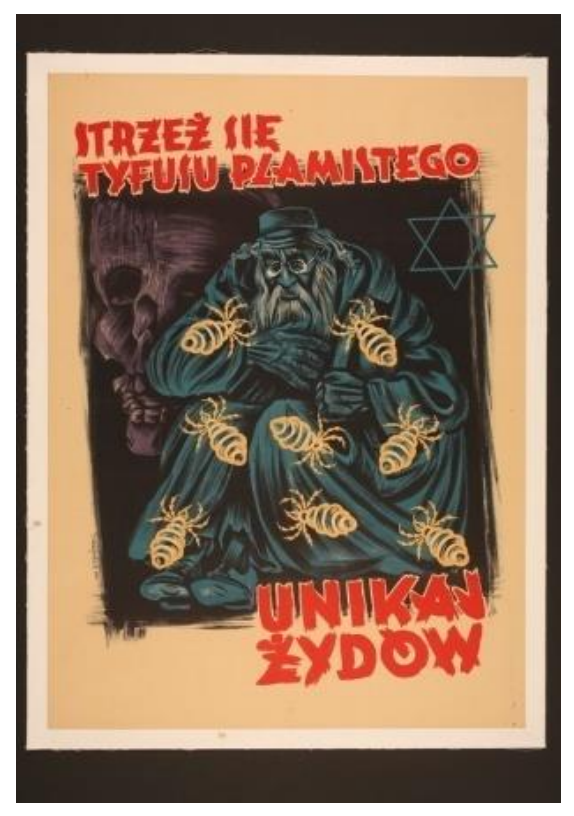

Tablo 2. "Hastalık" Konulu Propaganda Posteri

\begin{tabular}{|c|c|}
\hline Düzanlam & Yaşlı bir Yahudi'nin tifüs hastalığına yakalanmış olması \\
\hline Yananlam & $\begin{array}{c}\text { Yahudilerin temizlik yapmadığı bu yüzden de hastalık taşıdı̆̆ iddia } \\
\text { edilmektedir }\end{array}$ \\
\hline Mit & $\begin{array}{c}\text { Musevi dinine mensup insanlar temizlenmez ve bu yüzden hastalık } \\
\text { saçarlar }\end{array}$ \\
\hline Metafor & Kuru kafa ölüm metaforu olarak kullanılmaktadır \\
\hline Simge & Altıgen yıldız Musevilik dinini temsil etmektedir \\
\hline Metonimi & $\begin{array}{c}\text { Posterde resmedilen yaşlı Yahudi tüm Yahudilerin metonimi olarak } \\
\text { kullanılmaktadır }\end{array}$ \\
\hline
\end{tabular}


Nazi propagandasının poster üzerinden vermek istediği mesajlar yananlam açısından değerlendirildiğinde, posterde doğrudan Polonya halkının Yahudilerden uzak durması için "Musevi dinine mensup insanlar temizlenmez ve bu yüzden hastalık saçarlar" şeklinde propaganda mitinin inşa edilmeye çalışıldığ1 görülmektedir. Bu amaçla posterde tifüs olduğu belirtilen yaşlı bir Yahudi adamın görseline yer verilmiştir. Görsel kodlar içerisinde yaşlı adamın tifüs olduğu üzerindeki büyük böceklerden, Yahudi olduğu sol üstünde bulunan altıgen yıldızdan ve ölüme yol açacağı düşüncesi de sağında bulunan kuru kafa resimden anlaşılmaktadır. Bu açıdan posterde yer alan kuru kafa doğrudan ölüm metaforu olarak yansitılmaktadır. Posterde Naziler, Polonya halkının Yahudiler ile evlendiklerinde veya ilişki kurduklarında tifüs hastalığına kapılacaklarını ve daha sonra bu hastalık yüzünden hayatlarını kaybedeceklerini iddia etmiştir. Ayrıca "Kendinizi Tifüs'ten Koruyun, Yahudilerden Kaçının" şeklindeki yazılı kodlar üzerinden de propaganda posterinde verilmek istenen mesaj doğrudan kitlelere aktarılmaktadır. Naziler, işgal sırasında Polonya halkının yardım etmek amacıyla Yahudilerin yanına gelebileceği veya Yahudileri evlerinde saklayabileceği düşüncesiyle böyle bir propaganda faaliyetine yönelme gereği duymuştur. Bu şekilde Polonyalıların Yahudilerden uzak duracağı ve hatta doğrudan saklandıkları yerleri Alman yetkililere bildirebileceği planlanmıştır.

\section{3. "Düşman" Konulu Propaganda Posteri}

"Düşman" konulu propaganda posteri düzanlam açısından incelendiğinde, posterde yıkıntılar içerisinde bir şehir ve şehrin üzerinde de kırık bir çarmığa gerilmiş sözde Hz. İsa temsilinin olduğu görülmektedir. Poster, 1943 yılında Nazi propagandası tarafından kullanılmıştır. Görsel kodlarda şehir yıkıntılarının hemen üzerinde siyahlar içerisinde büyük bir adam görseline yer verilmiştir. Sunum kodlarında adamın gözlerini sert bir edayla sözde Hz. İsa'nın temsiline yönelttiği görülmektedir. Posterde "Smiertelny wrog Chrzescijanstwa / Hıristiyanlığın Ölümcül Düşmanı" şeklinde yazılı kod bulunmaktadır. 


\section{Resim 3."Düşman" Konulu Propaganda Posteri}

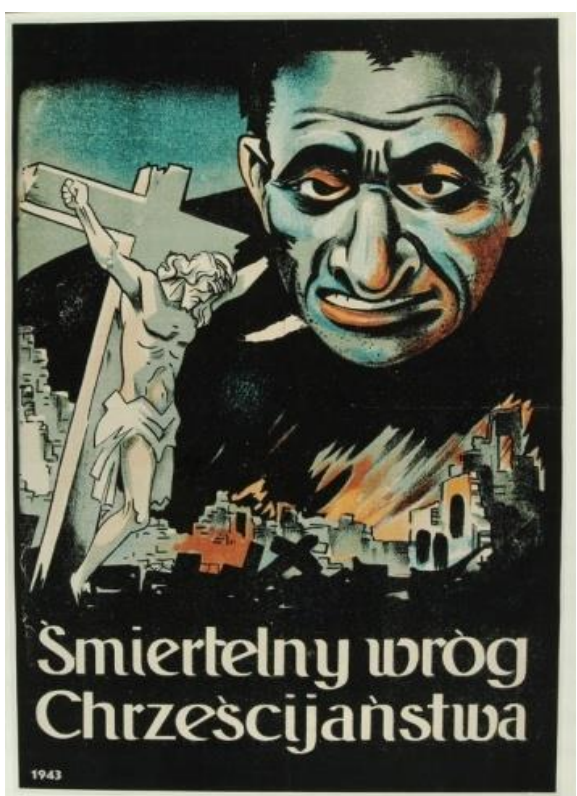

Poster yananlam boyutunda analiz edildiğinde, posterde Nazi propagandası tarafından Musevilik dininin doğrudan Hristiyanlık dininin en büyük düşmanı olarak yansıtıldığı görülmektedir. Posterde yer alan sözde Hz. İsa temsili, Hıristiyanlık dinini temsil etmektedir. Yıkılan şehir görseli, sözde Yahudiler nedeniyle zarar gören Hıristiyan yerleşim yerlerinin metonimi olarak kullanılmaktadır. Görsel kodlar içerisinde sözde Hz. İsa temsilinin yıkıntılar içerisinde bulunması ve Yahudi görselinin gözleri ile sözde Hz. İsa temsilini izlemesi ile Hıristiyanlığın başına gelen tüm felaketlerden Yahudiler sorumlu tutulmaya çalışılmıştır. Diğer yandan Yahudi görseli, korku metaforu olarak kullanılmaktadır. Posterde görsel ve yazılı kodlar birlikte ele alığında Nazilerin, "Musevilik dinine mensup insanlar Hıristiyanlık dininin baş düşmanıdır" şeklindeki miti Polonya kamuoyunda inşa etmeye çalıştığı ortaya çıkmaktadır. Böylece Hıristiyanlık ve Musevilik dini arasında geçmiş dönemlerde yaşanan düşmanlıklar tekrar hatırlatılarak, Polonya halkında Yahudilere yönelik nefret duygusu oluşturulmaya çalışılmaktadır. Bu şekilde Polonya halkının Yahudilerden nefret etmesi ve Alman yetkiler ile iş birliği içine girmesi amaçlanmaktadır. 
Tablo 3. "Düşman" Konulu Propaganda Posteri

\begin{tabular}{|c|c|}
\hline Düzanlam & $\begin{array}{l}\text { Yahudi bir adamın yıkıntılar içerisindeki sözde Hz. İsa } \\
\text { temsiline bakması }\end{array}$ \\
\hline Yananlam & $\begin{array}{l}\text { Yahudilerin İkinci Dünya Savaşı'nda yaşanan yıkımdan } \\
\text { sorumlu tutulması ve Hıristiyanlığı hedef alan eylemlere } \\
\text { yöneldiğinin iddia edilmesi }\end{array}$ \\
\hline Mit & $\begin{array}{l}\text { Musevilik dinine mensup insanlar Hıristiyanlık dininin baş } \\
\text { düşmanıdır }\end{array}$ \\
\hline Metafor & Yahudi görseli, korku metaforu olarak kullanılmaktadır \\
\hline Simge & $\begin{array}{l}\text { Çarmığa gerilmiş sözde Hz. İsa temsili Hıristiyanlık dinini } \\
\text { temsil etmektedir }\end{array}$ \\
\hline Metonimi & $\begin{array}{c}\text { Yıkılan şehir görseli, sözde Yahudiler nedeniyle zarar gören } \\
\text { Hıristiyan yerleşim yerlerinin metonimi olarak } \\
\text { kullanılmaktadır }\end{array}$ \\
\hline
\end{tabular}

\section{4. "Tehdit" Konulu Propaganda Posteri}

"Tehdit" konulu propaganda posteri düzanlam boyutunda ele alındığında, posterde 32. ABD Başkanı Franklin Delano Roosevelt'in görseline yer verilmiştir. Poster, 1944 yılında Nazi propagandası tarafından kullanılmıştır. Görsel kodlar içerisinde Roosevelt, ağzındaki piposuyla aynaya bakmaktadır. Buna karşın aynada kendisinin haricinde bir de Yahudi bir adamın olduğu görülmektedir. Sunum kodlarında aynaya bakan Roosevelt'in tıraşlı, kendinden emin ve dinç olduğu yansıtılırken, aynadaki yansıması ise tam tersi bitkin, sakallı ve ümitsiz bir bakış içerisindedir. Posterde "W zwierciadle samokrytycyzm / Kritik kendini yansıtma aynasında" şeklinde yazılı kod bulunmaktadır. 
Resim 4. "Tehdit" Konulu Propaganda Posteri

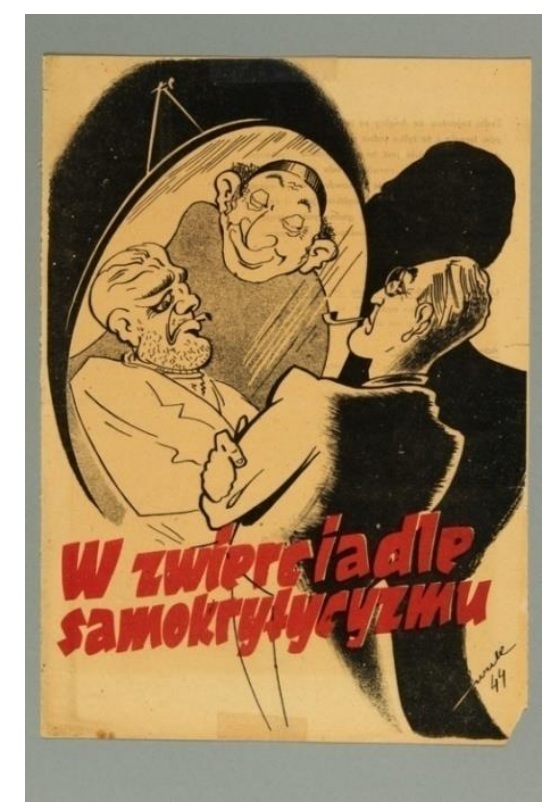

Poster yananlam açısından ele alındığında, posterde Yahudilerin dünyayı yönetenler üzerinde kimi zaman tahakküm kurarak halka zulmettikleri mitinin inşa edilmeye çalışıldığı görülmektedir. Posterde yer alan Yahudi görseli ABD'de yaşayan tüm Yahudilerin, ABD lideri ise Nazi Almanya'sına karşı mücadele veren tüm siyasi liderlerin metonimi olarak kullanılmaktadır.Bu aşamada ABD Başkanı Roosevelt'in görseline yer verilerek, ABD yönetiminin de Yahudilerin nüfuzu altına girdiği iddia edilmiştir. Böylece posterde Yahudi görseli, tehdit metaforu olarak kullanılmıştır. Roosevelt'in görünüşte Nazi Almanyası ile savaşması demokrasi ve insan hakları için değil doğrudan Yahudiliğe hizmet için olduğu aktarılmıştır. Görsel kodlarda Roosevelt'in kararlı dış görünüşünün altında tamamen Yahudilerin söylemleri altında hareket eden bitkin biri olduğu yansıtılmıştır. Bu şekilde Nazi Almanya'sının onlarca ülke ile aynı anda savaşmasının Yahudiler tarafından düzenlenen kargaşa ortamının bir sonuncu olarak ortaya konulması amaçlanmıştır. Naziler, posterde Polonya kamuoyunda Müttefik Devletleri'ne karşı vermiş oldukları mücadelenin meşruluk kazanmasını amaçlamış, aynı zamanda Yahudilerin dünya milletleri için ne kadar tehlikeli olabileceği aktarılmaya çalışılmıştır. Naziler böylece kendileri üzerinde oluşan 
"işgalci" algının da ortadan kalkmasını ve Polonya halkının Yahudiler konusunda kendileri ile iş birliği içerisine girmesini istemiştir.

Tablo 4. "Tehdit" Konulu Propaganda Posteri

\begin{tabular}{|c|c|}
\hline Düzanlam & Roosevelt'in aynaya bakması \\
\hline Yananlam & $\begin{array}{r}\text { Roosevelt'in İkinci Dünya Savaşı'nda doğrudan Yahudilerin } \\
\text { nüfuzu altında bulunduğu iddia edilmektedir }\end{array}$ \\
\hline Mit & $\begin{array}{c}\text { Musevi dinine mensup insanlar devlet liderlerini tahakkümü } \\
\text { altına alabilmektedir }\end{array}$ \\
\hline Metafor & Yahudi görseli, tehdit metaforu olarak kullanılmaktadır \\
\hline Simge & $\begin{array}{c}\text { Ayna, sözde Yahudiler ve Roosevelt arasındaki bağ1 } \\
\text { simgelemektedir }\end{array}$ \\
\hline Metonimi & $\begin{array}{c}\text { Posterde yer alan Yahudi görseli ABD'de yaşayan tüm } \\
\text { Yahudilerin metonimi olarak kullanılmaktadır }\end{array}$ \\
\hline
\end{tabular}

\section{5. "Kötülük" Konulu Propaganda Posteri}

"Kötülük" konulu propaganda posteri düzanlam açısından incelendiğinde, posterde üç farklı Yahudi'nin çalışmasına yer verilmektedir. Poster, 1940 yılında Nazi propagandası tarafından kullanılmıştır. Posterde soldan sağa Yahudilerin, fırıncı, sütçü ve kasap olarak çalıştığı aktarılmaktadır. Görsel kodlar içerisinde fırıncı olan Yahudi'nin hamuru ayakları ile yoğurduğu, sütçü olan Yahudi'nin süte su karıştırdığı, kasap olan Yahudi'nin ise kıyma makinesine fare attığı yansitılmaktadır. Posterde "Zyd tooszust jedyny twoj wrog/Yid (Yahudi) bir hileci ve sadece senin düşmanın" şeklinde yazılı kod bulunmaktadır. 
Resim 5. "Kötülük" Konulu Propaganda Posteri

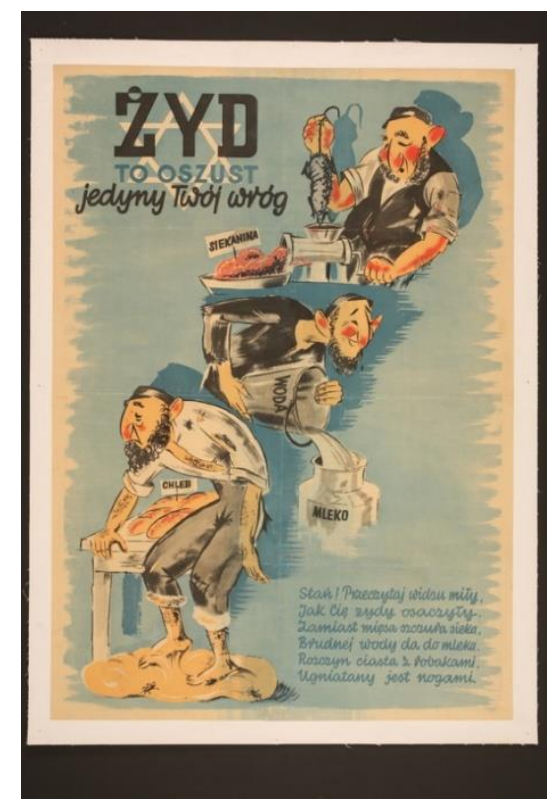

Poster yananlam boyutunda analiz edildiğinde, posterde Nazi propagandası tarafından doğrudan Polonya halkı üzerinde "Musevilik dinine mensup insanlar, kendileri dışındaki herkese kötülük yapmaktadır" şeklinde mitin inşa edilmeye çalışıldığ1 görülmektedir. Posterde resmedilen Yahudiler tüm Yahudilerin metonimi olarak kullanılmaktadır. Bu şekilde Yahudilerin çalıştıkları işlerde her türlü kötülüğü yapabildiği, insan sağlığını hiçe saydığı, insanları sattıkları ürünler konusunda kandırdığı gibi algıların kamuoyunda hâkim kılınması için çalışılmaktadır. Böylece Yahudilerin doğrudan kötülük metaforu olarak insanların zihinlerinde yer etmeleri istenmiştir. Nazi propagandası özellikle Polonya halkının Yahudilerden alışveriş yapmamasını ve onlardan uzak durmasını telkin etmiştir. Bu şekilde Naziler, Yahudilere karşı oluşturdukları önyargılar ile Polonya halkından destek görebileceklerini ve Yahudileri gerektiğinde kendilerine ihbar edebileceklerini planlamıştır. 
Tablo 5. "Kötülük" Konulu Propaganda Posteri

\begin{tabular}{|c|c|}
\hline Düzanlam & Yahudi esnafın çalışması \\
\hline Yananlam & $\begin{array}{r}\text { Yahudiler temiz değildir ve yaptıkları işlerde kar elde edebilmek } \\
\text { için her türlü sahtekarlığı yapabilir iddiası }\end{array}$ \\
\hline Mit & $\begin{array}{c}\text { Musevilik dinine mensup insanlar, kendileri dışındaki herkese } \\
\text { kötülük yapmaktadır }\end{array}$ \\
\hline Metafor & Yahudi görselleri, kötülük metaforu olarak kullanılmaktadır \\
\hline Simge & Altıgen yıldız Musevilik dinini temsil etmektedir \\
\hline Metonimi & $\begin{array}{c}\text { Posterde resmedilen Yahudiler tüm Yahudilerin metonimi olarak } \\
\text { kullanılmaktadır }\end{array}$ \\
\hline
\end{tabular}

\section{SONUÇ}

Çalışmada incelenen posterlerde antisemitist propaganda çerçevesinde Polonya'da yaşayan Yahudilere yönelik doğrudan nefret söylemi inşa edildiği görülmektedir. Posterlerde Yahudileri temsil eden görsellerin yalnızca Polonya'da yaşayan Yahudileri değil dünya genelindeki tüm Yahudilerin metonimi olarak kullanıldığı çalışma kapsamında ortaya çıkarılmıştır. Bu yolla Yahudilere karşı inşa edilen nefretin yalnızca Polonya'daki Yahudiler ile sınırlı kalmamasına çalışılarak, Yahudiler üzerinde genel bir nefretin oluşturulmasının amaçlandığı görülmüş̧ür. Yahudi metonimilerinin görsel ve yazılı kodlar üzerinden olumsuz şekilde aktarılması ve posterlerde Yahudilerin kötülük, tehdit, korku, ölüm, zulüm gibi olumsuz metaforlar üzerinden yansitılması ile Polonyaların Yahudilere yönelik ön yargı içerisinde olmasına çalışıldığı saptanmıştır.

Elde edilen bulgular kapsamında, Nazi propagandasının, posterler üzerinden Yahudilere yönelik zulüm, sağlık, din, başlıklarında üç temel antisemitist miti inşa 
Nazi Almanyası İşgalindeki Polonya'da Propaganda Posterleri Üzerinden Yahudilere...

etmeye çalıştığı ortaya çıkarılmıştır. Bunlar içerisinde "Yahudiler insanlığa zulmeder" şeklindeki antisemitist mit zulmü konu almaktadır. Nazi propagandası bu mitile Yahudilerin dünyadaki yegâne amaçlarının insanlığın kötülüğü için çalışmak olduğu yönündeki algıyı Polonya'da hâkim kılmayı amaçlamıştır. Bu şekilde Polonya halkının Yahudilere yapacakları yardımların insanlığın kötülüğüne hizmet olduğunu Nazi propagandası ifade etmiştir. Diğer yandan Nazilerin savaşın başından itibaren savundukları "Savaşın sebebi Yahudilerdir" iddiasının da bu mit ile meşrulaştırılması amaçlanmıştır. Böylece Naziler, Polonya halkında savaşa yönelik oluşan nefreti doğrudan Yahudilere odaklamaya çalışmıştır. Sağlık konulu ikinci mit ise "Yahudiler insanlığa hastalık saçarlar" şeklindeki antisemitist mittir. İnşa edilen bu mit ile Yahudilerin temizlikten uzak oldukları ve bu nedenle ölümcül hastalıklarda dâhil olmak üzere pek çok hastalığı bünyelerinde barındırdıkları algısının Polonya kamuoyunda oluşturulmasının amaçlandığı görülmüştür. $\mathrm{Bu}$ yolla Nazi propagandası, Polonyalıların Yahudilerden uzak durmasını, evlerinde Yahudileri saklamalarını önlemeyi, kendi sağlıkları için Yahudileri gördükleri yerde Alman yetkililere bildirilmelerini hedeflemiştir. Son olarak Naziler dini açıdan "Yahudiler, Hıristiyanlığın baş düşmanıdır" şeklinde antisemitist miti inşa etmeye çalışmıştır. Bu mitler üzerinden Polonya vatandaşlarının Yahudilerden uzak durması ve onları toplum içerisinde ötekileştirerek dışlamaları istenmiştir. Diğer yandan ülke genelinde Nazi rejimine karşı Yahudilere yönelik dışlama politikalarına karşı olan grupların söylemlerinin de marjinalleştirilerek ortadan kaldırılmasının amaçlandığı görülmüştür. Naziler, posterler üzerinden inşa ettikleri yapay anlamların kitleler üzerinde yapılan antisemitist propaganda yoluyla doğal anlamlara dönüşmesine çalıştı̆̆ ortaya çıkarılmıştır. Böylece Nazizm ideolojisinde yer alan antisemitist söylemlerin, Polonya halkı tarafından desteklenmesi ve kabul görmesi amaçlanmıştır. 
Çalışma kapsamında Nazi Almanya'sının işgali altında bulunan Polonya'da posterler üzerinden Nazi propagandası tarafından Yahudilere yönelik ne şekilde nefret söylemi inşa edildiği ortaya konulmaya çalışılmıştır. Çalışmada elde edilen bulgular propaganda aracılığı ile dini nefretin nasıl inşa edilebileceğini ortaya koyması bakımından önem taşımaktadır. Gelecek çalışmaların günümüzde Orta Doğu coğrafyasında güçlenen İsrail karşıtı propagandalardaki antisemitist söylemlerin, mevcut çalışmada elde edilen bulgular ile karşılaştırmalı olarak analiz edilmesinin alana katkı sağlayacağı düşünülmektedir.

\section{KAYNAKLAR}

Barthes R (2014) Çağdaş Söylenler, Tahsin Yücel (çev), 4. Baskı. Metis Yayınları, İstanbul.

Barthes R (2015) Bir Deneme Bir Ders: Eiffel Kulesi ve Açılış Dersi, Mehmet Rifat, Sema Rifat (çev), 2. Baskı, Yapı Kredi Yayınları, İstanbul.

Barthes R (2016) S/Z, Sündüz Öztürk Kasar (çev), Sel Yayıncılık, İstanbul.

Barthes R (2017) Görüntünün Retoriği, Sanat ve Müzik, Ayşenaz Koş, Ömer Albayrak (çev), 2. Baskı, Yapı Kredi Yayınları, İstanbul.

Beyerchen A D (2015) Nazi Dönemi'nde Bilim, 3. Reich'da Üniversite, Haluk Tosun (çev), 2. Baskı, Say Yayınları, İstanbul.

Çakı C (2018a) Adolf Hitler'in Kült Lider İnşasında Kullanılan Propaganda Posterlerinin Göstergebilimsel Analizi. Abant Kültürel Araştırmalar Dergisi, 3 (6), 24-38.

Çakı C (2018b) Nazizm İdeolojisi Altında Hitler Gençliği: Nazi Almanya'sı Propaganda Afişleri Üzerine İnceleme. Elektronik Cumhuriyet İletişim Dergisi, 1 (1), 9-21. 
Nazi Almanyası İşgalindeki Polonya'da Propaganda Posterleri Üzerinden Yahudilere...

Çakı C (2019) Antisemistist Mitlerin İnşasında Nazi Propagandasının Rolü. Karadeniz Teknik Üniversitesi Sosyal Bilimler Enstitüsü Sosyal Bilimler Dergisi, 9(17), 203-219.

Çakı C ve Gülada M O (2018a) Vichy Fransası'nda İşgal Propagandası. Trakya Üniversitesi İktisadi Ve İdari Bilimler Fakültesi Dergisi, 7(1), 53-80.

Çakı C ve Gülada M O (2018b) Nazizm İdeolojisinde Alman Kadınları: "NsFrauen-Warte" Propaganda Dergisi Üzerine İnceleme. Medeniyet ve Toplum Dergisi, 2(2), 89-105.

Çakı C, Gülada M O ve Çakı G (2018) Balkanlarda Bir Nazi Ordusu: Nazi Propaganda Afişlerinde Hançer Tümeni. Trakya Üniversitesi İktisadi ve İdari Bilimler Fakültesi Dergisi, 7(2), 55-77.

Dalerne J (2013) Gestapo, Doğuşu, Yükselişi ve Çöküşü, Muzaffer Sever (çev), 2. Asur Yayınları, İstanbul.

Domenach J M (2003) Politika ve Propaganda, Tahsin Yücel (çev), Varlık Yayınları, İstanbul.

Eberle H \& Uhl M (2017) Hitler Kitabı, Mustafa Tüzel (çev), Alfa Yayınları, İstanbul.

Fiske J (2017) İletişim Çalışmalarına Giriş, Süleyman İrvan (çev), 5. Basım, Bilim ve Sanat Yayınları, Ankara.

Gazi M A \& Çakı C (2018) Siyahi Ayrımcılığa Karşı Hazırlanan Kamu Spotu Reklamları. International Journal of Labour Life And Social Policy, 1(2), 48-62.

Gazi M A, Çakı C \& Gülada M O (2018) İspanya 2000 Partisi'nin Göçmen Karşıtı Propaganda Faaliyetleri Üzerine İnceleme. Ankara Uluslararası Sosyal Bilimler Dergisi, 1 (2), 11-22.

Goebbels J (2016) Gerçek Yüzüyle Komünizm ve Teori ve Pratikte Bolşevizm, Zehra Köroğlu (çev), Bilge Karınca Yayınları, İstanbul. 
Goodrick-Clarke N (1993) The Occult Roots of Nazism: Secret Aryan Cults and Their Influence on Nazi Ideology, University Press, New York.

Guiraud P (2016) Göstergebilim, Mehmet Yalçın (çev), 3. Baskı. İmge Kitabevi, Ankara.

Hart B L (2015) İkinci Dünya Savaşı Tarihi, Kerim Bağrıaçık (çev), İş Bankası Yayınları, İstanbul.

Hitler A (2004) Kavgam, Oktay Ertaş (çev), 2. Baskı, Beda Yayıncılık, İstanbul.

Hitler A (2005) Siyasi Vasiyetim, A. Naci Demirci (çev), Okumuş Adam Yayınları, İstanbul.

Hyams B (1995) Weininger and Nazi Ideology. In N. Harrowitz\& B. Hyams (Eds.), Jews and Gender: Responses to Otto Weininger (pp. 155-168). Philedelphia, PH: Temple University Press.

Jowett S G ve O'donnell V (2014) Propaganda \& Persuasion. Sage, USA.

Karaca M (2018) Waffen SS Askere Çağırma Propagandası, EUropean Journal of Managerial Research (EUJMR), 2(2), 100-118.

Keegan J (2016) İkinci Dünya Savaşı, Samet Öksüz (çev), Say Yayınları, İstanbul.

Kershaw I (2007) Hitler, 1889-1936: Hubris, Zarife Biliz (çev), 1. Cilt, İthaki Yayınları, İstanbul.

Kershaw I (2009) Hitler, 1936-1945: Nemesis, Zarife Biliz (çev), 2. Cilt, İthaki Yayınları, İstanbul.

Macit M H (2007) Faşizm ve Nazizm, Savaş Yayınevi, İstanbul.

Macksey K J (2012) İkinci Dünya Savaşı'nda Askeri Hatalar, M. Tanju Akad (çev), İş Bankası Kültür Yayınları, İstanbul.

Mazower M (2014) Hitler İmparatorluğu, İşgal Avrupa'sından Nazi Yönetimi, Yavuz Alogan (çev), 2. Baskı, Alfa Yayınları, İstanbul. 
Nazi Almanyası İşgalindeki Polonya'da Propaganda Posterleri Üzerinden Yahudilere...

Mcdonough F (2015) The Gestapo: The Myth And Reality of Hitler's Secret Police, HachetteUk, The United Kingdom.

Mcmahon J R (2013) Soğuk Savaş, Sinem Gül (çev), Dost Kültür Yayınları, Ankara. Mcnab C (2015) Hitler'in Ordusu, Nazi Savaş Makinesinin Tarihi, 1939-1945, Okan Doğan (çev), Timaş Yayınları, İstanbul.

Murray J W (1998) Constructing the Ordinary: The Dialectical Development of Nazi Ideology, Communication Quarterly, 46(1), 41-59.

Mussolini B (2016) Faşizm, Hasan Tuncay (çev), Toker Yayınları, İstanbul.

Neumann F L (2009) Behemoth: The Structure And Practice of National Socialism, 1933- 1944, Chicago, IL: Ivan R. Dee.

Passmore K (2014) Faşizm, Sinem Gül, (çev), Dost Yayınları, Ankara.

Rifat M (2013) Açıklamalı Göstergebilim Sözlügü: Kavramlar, Yöntemler, Kuramcılar, Okullar, Türkiye İş Bankası Kültür Yayınları, İstanbul.

Seiler B (1966) Dolchstoß" und" Dolchstoßlegende, Zeitschrift für deutsche Sprache, 1-22.

Stanley J (2018) Demokrasilerde Propaganda Oyunu, Başak Karal (çev), The Kitap Yayınları, İstanbul.

Tanyeri Mazıcı E \& Çakı C (2018) Adolf Hitler'in Korku Çekiciliği Bağlamında Kamu Spotu Reklamlarında Kullanımı, Erciyes İletişim Dergisi, 5(3), 290-306.

Tekinalp Ş \& Uzun R (2013) İletişim Araştırmaları ve Kuramları, 4. Baskı, Derin Yayınları, İstanbul.

Yavuzoğlu A (2003) 20. yy ‘da Faşist Paranoya, Sayfa Yayınları, İstanbul.

Yaylagül L (2017) Kitle İletişim Kuramları, Egemen ve Eleştirel Yaklaşımlar, 8. Baskı, Dipnot Yayınları, Ankara. 
Selçuk İletişim, 2019, 12 (2): 781-812

Yücel E (2017) Propaganda, Hitler'in Müftüsünden Nazi Türklere, Bir Diktatörün Otopsisi, Karakarga Yayınları, İstanbul.

Zorlu Y, Çakı C \& Karaca M (2017) Türk Sinemasında Nazizm İdeolojisi: “Kırımlı” Filmi ve Göstergebilimsel Analizi, Sosyoloji Konferansları, (56), 67-95. 